\title{
Changes of genetic variances and heritability by effect of selection in a Mexican local variety of Squash
}

\begin{abstract}
Summary
A local variety of squash (Cucurbita pepo L.), 'Round Zuchinni' type from Los Reyes Acatlixhuayan State of México, México, was simultaneously evaluated and selected. The objective was to study effect of selection on genetic variance and heritability. Additive genetic variance decreased in seven of nine traits studied: fruit height (79.93\%); fruit weight (65.72\%); fruit width (60.91\%); flesh thickness (57.66 \%); flesh color (43.70\%); dry weight of seed (39.54\%); flesh flavor (16.60\%); except in width and seed length traits where it increased $63.40 \%$ and $0.81 \%$, respectively. Only weight of seed had dominance genetic variance. The coefficient of additive genetic variance $\left(\mathrm{CV}_{\mathrm{A}}\right)$ fluctuated from 9.4 to $61.7 \%$ in the first cycle, and from 9.4 to $51.8 \%$ in the second cycle of selectionevaluation among traits. Heritability diminished in seven from nine characters. In general, the estimated genetic variances (additive and dominance) and heritability decreased as a result of combined selection of falf sib families.
\end{abstract}

Keywords: cucurbita pepo, genetic variance, heritability, participatory selection
Volume 7 Issue 5 - 2020

Clemente Villanueva-Verduzco,' José Antonio Ayala-Esteban,' Evert Villanueva-Sánchez, ${ }^{2}$ Jaime Sahagen-Castellanos,' Irma Sánchez Cabrera, ${ }^{3}$ Laura Chaning Merrick, ${ }^{4}$ Martha Blanca Guadalupe Irizar Garza ${ }^{5}$

'Departamento Fitotecnia, Universidad Aut noma Chapingo, Mexico

${ }^{2}$ CONACYT-Universidad Aut noma Chapingo, Laboratorio Nacional Investigacin Servicio Agroalimentario y Forestal, Mexico

${ }^{3}$ Recursos Genticos y Productividad Oreintacin Gentica, Mexico ${ }^{4}$ Deparment of Agronomy, lowa State University, USA ${ }^{5}$ Instituto Nacional Investigaciones Forestales, Agrcolas Pecuarias , Mexico

Correspondence: Clemente Villanueva-Verduzco, Departmento de Fitotecnia, Universidad Aut noma Chapingo, Carretera Mexico, Email clement.villanueva@gmail.com

Received: October 04, 2020 | Published: October 15, 2020

\section{Introduction}

Pumpkins (Cucurbita spp.) are crops of high importance at worldwidth level and a central part of the diet in many regions of the world. They have been part of man's diet in mesoamerica for more than 10000 years. ${ }^{1}$ The oldest archaeological records of the Cucurbita genus correspond to remains of gourds (seeds and fruit fragments) of C. pepo from about 8,000 years ago in the Guilá Naquitz cave, in Oaxaca, México. Thus, pumpkins were the first domesticated plants in Mexico, perhaps thousands of years before corn and beans, which later, together, were part of the basic food production of mesoamerican multi cropping system known as milpa. ${ }^{2}$ The genetic diversity of pumpkins in Mexico is very width in species, shape, size and color of fruit, quantity of seed, quality and thickness of flesh, tolerance to diseases and precocity, among other characteristics. ${ }^{3}$ Genetic variation is the raw material of genetic improvement, and in a population it can be measured by molecular and quantitative methods.

By molecular methods, it is not possible to know the types of variance (additive, dominance and epistatic) traditionally useful for genetic improvement of metric traits, but that technology can support the breeding assisted by molecular markers, which are less affected than the phenotype by environmental effects. Molecular studies of genetic variation in Mexican pumpkin populations from four species (Curcubita argyrospermar, C. pepo, C. moschata and C. ficifolia) are due to: Cerón-Gonzalez et al., ${ }^{4}$ Sánchez de la Vega et al., ${ }^{5}$ (C. pepo, $C$. argyrosperma) and Mendez-López et al., ${ }^{6}$ (C. pepo).

Quantitatively, the variation of metric traits is expressed and measured through the variance. ${ }^{7}$ The response to recurrent selection depends on the magnitude of genetic variance present in the population. The relative magnitude of genetic variance components (additive, dominance, epistatic) indicate to the breeder if the base population has sufficient genetic variability and the most appropriate breeding method to apply. ${ }^{8,9}$ The heritable proportion of genetic variance is broken down into an additive portion associated with the average effect, of the effects of the genes; a portion of dominance, due to the intralocus allelic interaction and the epistatic due to the interlocus interactions of series of intralocus gene actions. If the additive variance exceeds to the dominance variance, it is preferable to improve by selection methods; conversely, improve by hybridization, and if they are of a similar magnitude, breeding methods (hybridization and selection). ${ }^{8,10-12}$

Additive variance is that which is inherited from parents to their offspring only by transmission of genes and it determines the response to selection. The existence of additive variance is desirable in recurrent selection programs that aim to accumulate favorable genes to improve desirable traits in a population perse. ${ }^{9}$ Quantitative studies of genetic parameters and analysis of genetic variance in Mexican squash germplasm have been made by Sánchez-Hernández et al., ${ }^{13}$ in C. argyrosperma var. Stenosperma, who found that: genetic parameters change with la variety; the heritability (narrow sense) fluctuated among 6.0 to $91.9 \%$; heritability for seed weight chaged from 49.4 to 57.6; exists genetic variance; after a cycle of combined selection of maternal half sib families (best plants from best families) the total genetic variance was determined mainly by additive effects of the genes in 13 metric traits of plant, fruit and seed, and the additive genetic variance decreased: $48.35 \%, 26.37 \%, 40.17 \%$ and $33.64 \%$ for fruit weight, seed weight, flesh thickness and flesh color, 
respectively, in a population previusly improved by five cycles of in situ participatory mass selection. The recurrent selection changes directly the gene frequencies. Consequently, the genetic variance change too and it also depends on the type of predominant gene action. In the limit of the selection, the genetic variance disappear as final result, when the allele frequencies are one and cero, respectively. When the additive variance decline, it is necessary to consider the possibility of changing the selection method or to change toward hybridization. ${ }^{14}$ The objective of this study was to know the changes in the components of genetic variance and heritability of metric traits by effect of selection in a local squash variety (Cucurbita pepo L.)

\section{Materials and methods}

Location: The experiments were carried out in of Los Reyes Acatlixhuayan, Municipality of Temamatla, State of Mexico, Mexico; located geographically to $19^{\circ} 16^{\prime}$ of North latitude and $98^{\circ} 54^{\prime}$ of west lengthitude, with 2240 meters above sea level at $70 \mathrm{~km}$ from México city. In two years 2000 and 2001, in rainfall conditions. The climate, is tempered subhumid with summer rains $(\mathrm{C}(\mathrm{CWo})(\mathrm{W})(\mathrm{i}.) \mathrm{g}$. The annual average temperature is $15.1^{\circ}$ and precipitation is of $656.9 \mathrm{~mm}$, being February the driest month and July the rainiest month. The soil of this region is constituted by volcanic and alluviums lands.

Plant material: Half sib families derived from third and fourth cycle of in situ participatory mass selection of local bushy Round Zucchini type variety introgressed with local landraces but maintained as bushy by the cooperator farmer Mr. Nolberto Cristalinas harvesting fruits labeled with a X produced by bush plants (Figure 1); and the commercial hybrid grey zucchini "Tala", intercropping one row each 15 squash families in order to measure the soil variation.

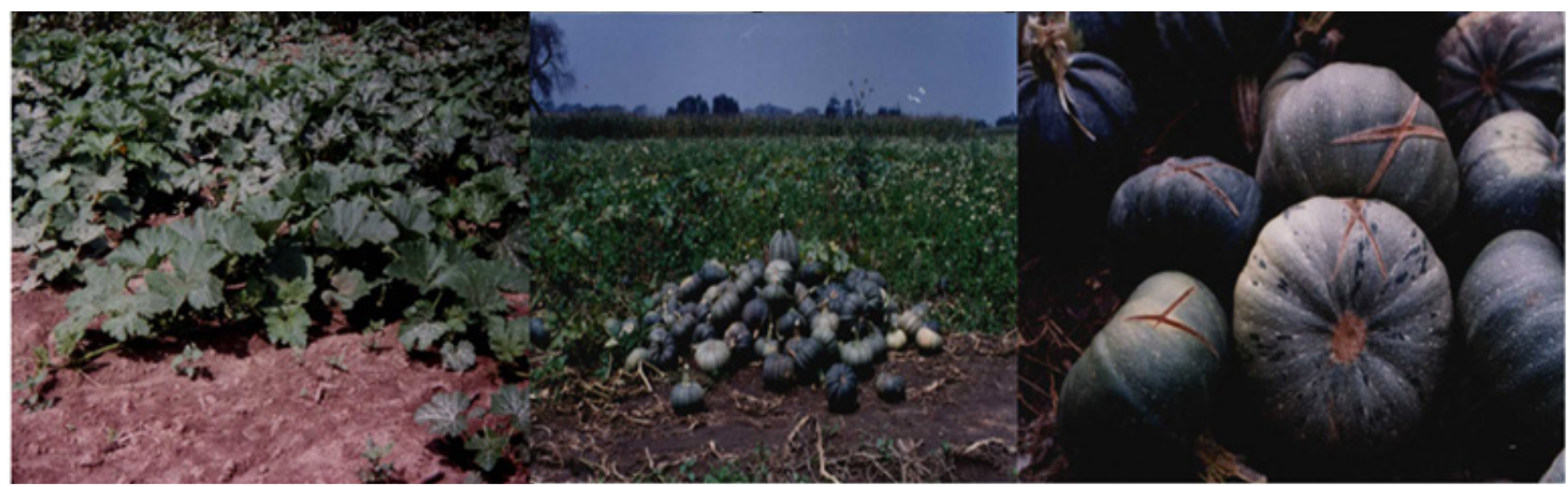

Figure I Local bush variety type round zucchini of cooperating farmer Mr Norberto Cristalinas. X fruits harvested of bush plants. Los Reyes Acatlixhuayan, Temamantla, State of México.

\section{In situ participatory mass selection (1996-1999)}

The studied variety had had four cycles of mass selección before the two cycles of combined of half sib family selection with simultaneus evaluation made for this study. For mass selection, the plot consisted of five blocks of 60 rows of $10 \mathrm{~m}$ length (300 total rows of 20 plants each, with a total of 6000 squash plants in the plot), with $2 \mathrm{~m}$ of separations between each block. Three rows were placed on each side and $5 \mathrm{~m}$ of board at both headers, of selection plot. The rows were separated at $1 \mathrm{~m}$ and the plants at $50 \mathrm{~cm}$. Stratification was made con 60 subplots; a plot each 5 rows. Mass selection criterion was made up with bushy plant, earliness, fruit and seed yield, fruit size and fruit quality (thickness $(\mathrm{cm})$, pulp color (scale, 1: intense orange, 2: orange, 3: intense yellow, 4: yellow, 5: light yellow and 6: white) and pulp flavor (scale, 1: very sweet; 2 : sweet and 3: insipid). The total selection pressure was $5 \%(0.2 \times 0.25=0.05)$; in the field, $20 \%$ was applied ( 6000 plants $\times 0.2=1,200$ best plants, based on earliness and fruit weight $(\mathrm{kg}))$; and in the farmer's house, $25 \%$ (1200 x $0.25=300$ best plants), applied based on seed yield and fruit quality (thickness $(\mathrm{cm})$, color and flavor of pulp). Only the best fruit per plant per selected plant in the field was brought to the farmer's house. The plot management included application of $100 \mathrm{~g}$ of caw manure over each hole at sowing time. Before second cultivation (1.5 months after sowing), the formula 100-40-00 NPK and mechanical weed control.

\section{Simultaneous combined selection and evaluation of families}

Combined selection: Mass selection (better plants) into better half sib families was made. Families were derived from the third and four cycles of selection (2000 and 2001). Progeny of each 120 selected plants in per year were simultaneously evaluated as a family. Selection within families: The best three plants per family were obtained by mass selection (selection pressure within (bW) families of 50\%). The selection criterion was based on seed yield and fruit quality (thick and sweet flesh with strong yellow or orange flesh color).

Selection between families: All mature fruits of each family were harvested in a single labor, at the end of the biological cycle. In order to continue the selection process, the best 40 families were selected based on the total weight (yield) of fruits by family and the number of fruits by family. The selection pressure between families (bE) was $33.3 \%$. That is, the 40 better families (bE: $120 \times 0.33=$ 40). Finally, only the three better plants of the 40 better families were selected in order to complete 120 families (fruits) for continuing the selection process. The crop management included application of $100 \mathrm{~g}$ of caw manure over each hole at sowing time. Before second cultivation (1.5 months after sowing), the formula 100-40-00 NPK and mechanical weed control. Adjusted data of families: It was based on the estratification of the selection plot with subplots of five rows (families) according with the formula proposed by Molina. ${ }^{15}$ It can remove part of the enviremental effect in slecction plot. It is described as below:

$\hat{Y}_{i j}=Y i j-\bar{Y} . j+\bar{Y} .$. for: $\mathrm{i}=1,2, \ldots ., \mathrm{n}$ families $(120) ; \mathrm{j}=1,2, \ldots ., \mathrm{n}$ subplots (60). where: $\hat{Y}_{i j}$ is the adjusted measurement of the $i$ family in the $j$ subplot; $\mathrm{Y}_{i j}$ is the observed measurement of the $i$ family in the $j$ subplot; $\bar{Y} . j$. is the average measurement of the families from $j$ subplot and Y.. is the general average families measurement en the selection plot. 


\section{Studied traits}

Same traits were evaluated in families and in the Tala hybrid. They were fruit weight $(\mathrm{FW} ; \mathrm{kg})$; fruit height $(\mathrm{FH} ; \mathrm{cm})$; fruit diameter $(\mathrm{FD}$; $\mathrm{cm})$; pulp thickness (PT; $\mathrm{cm})$; pulp color (PC; scale, 1: strong orange; 2: orange; 3: strong yellow; 4: yellow; 5: light yellow and 6: white; lower scalar value correspond to better pulp color); pulp flavor (PF; was measured tasting a pulp portion considering the scale, 1: very sweet; 2: sweet and 3: insipid; smaller scalar value correspond to better pulp flavor); width and lengthth of seed (WS and LS; $\mathrm{cm}$ ) and dry weight of seed per fruit (DWS; g).

\section{Statistical analysis}

\section{Evaluation of Families (2000, 200I)}

The same experiment was designed for evaluation and combined selection of hFH sib families at same time, with the purpose of do not stop the selection process in the local variety. The experiment was sown with 120 families in a plot of the cooperating farmer, during Spring - Summer seasons. Each family was sown in two rows of 25 $\mathrm{m}$ in lengthth with three plants per hole each meter. Distance among rows was $80 \mathrm{~cm}$. The experimental surface was $5,600 \mathrm{~m}^{2},(37,500$ plants.ha $\left.{ }^{-1}\right)$. Data were collected by single plant into families in order to make possible the estimation of genetic parameters. The analysis of variance with the model 1 represents the evaluation of $f$ families (F), $r$ blocks (B) and $p$ plants per block per family (P) for data per plant, as follows: $\mathrm{Y} i j k=\mu+\mathrm{F} i+\mathrm{B} j+(\mathrm{FB}) i j+\mathrm{P}(i j) k$; where Yijk is the observed value of the $k t h$ plant within the $j$-th block of the $i$-th family, $\mu$ is the mean, Fi is the effect of the $i$-th family, B $j$ the effect of the $j$-th block, (FB) $i j$ the effect of interaction between the $i$-th family and the $j$-th block and $\mathrm{P}(i j) k$ the effect of the $k$-th plant within the $j$-th block of the $i$-th family. The form of the analysis of variance is described in Table 1.

Table I Form of the analysis of variance for $f$ families $(F), r$ blocks $(R)$ and $p$ plants per block per family (P). Model I

\begin{tabular}{llll}
\hline $\begin{array}{l}\text { Variation } \\
\text { Sources }\end{array}$ & $\begin{array}{l}\text { Degrees of } \\
\text { freedom }\end{array}$ & $\begin{array}{l}\text { MeLS } \\
\text { Squares }\end{array}$ & $\begin{array}{l}\text { Hopes of MeLS } \\
\text { Squares }\end{array}$ \\
\hline Blocks (B) & $\mathrm{r}-\mathrm{I}$ & - & - \\
Families (F) & $\mathrm{f}-\mathrm{I}$ & $\mathrm{MI}$ & $\sigma_{n}^{2}+n \sigma_{f}^{2}$ \\
$\mathrm{~B} \times \mathrm{F}$ & $(\mathrm{b}-\mathrm{I})(\mathrm{f}-\mathrm{I})$ & $\mathrm{M} 2$ & $\sigma 2 \mathrm{pw}+\mathrm{p} \sigma 2 \mathrm{rf}$ \\
Plants/(BxF) & $(\mathrm{p}-\mathrm{I}) \mathrm{rf}$ & $\mathrm{M} 3$ & $\sigma 2 \mathrm{pw}$ \\
Total & $\mathrm{rfn-l}$ & - & - \\
\hline
\end{tabular}

Evaluation of zucchini hybrid: Twenty rows of $25 \mathrm{~m}$ were established with holes of four plants every $50 \mathrm{~cm}$. Sown holes were thinned to three plants per hole, 10 days after germination. One row of the hybrid was distributed every six families (rows) of the local variety of pumpkin under study. The number of fruits per plant (NFP), and biological yield (RB; g) were quantified with a clock-type scale. The model (model 2) used in the statistical analysis for the hybrid 'Zucchini Tala' was: Yijk $=\mu+\mathrm{A} i+\mathrm{M} j(i)+\mathrm{P} k(i j)$; where $\mathrm{Y} i j k$ is the observed value of the $k t h$ plant in the $j$-th hole of the $i$-th area (or row), $\mu$ is the trait mean of the experiment, $\mathrm{A} i$ is the effect of the $i$-th area, $\mathrm{M} j(i)$ the effect of the $j$-th Hole in the $i$-th area and $\mathrm{P} k(i j)$ the effect of $k$-th plant within the $j$-th plant of the $i$-th area. The form of its analysis of variance is described in Table 2.
Table 2 Form of the analysis of variance for a areas (A), $r$ holes $(M)$ and $p$ plants per Hole per area (P). Model 2

\begin{tabular}{llll}
\hline $\begin{array}{l}\text { Variation } \\
\text { Sources }\end{array}$ & $\begin{array}{l}\text { Degrees of } \\
\text { freedom }\end{array}$ & $\begin{array}{l}\text { MeLS } \\
\text { Squares }\end{array}$ & $\begin{array}{l}\text { Hopes of MeLS } \\
\text { Squares }\end{array}$ \\
\hline Areas $(\mathrm{A})$ & $\mathrm{a}-\mathrm{I}$ & - & - \\
Holes/areas $(\mathrm{M})$ & $(\mathrm{r}-\mathrm{I}) \mathrm{a}$ & $\mathrm{MI}$ & $\sigma 2 \mathrm{we}+\mathrm{p} \sigma 2 \mathrm{~m} / \mathrm{a}$ \\
Plant/holes $(\mathrm{P})$ & $(\mathrm{p}-\mathrm{I}) \mathrm{ra}$ & $\mathrm{M} 2$ & $\sigma 2 \mathrm{we}$ \\
Total & pra-I & - & - \\
\hline
\end{tabular}

\section{Genetic variances and heritability}

Family structure of maternal half sib families was used to estimate components of genetic variance, following the methodology proposed by Márquez and Sahagún. ${ }^{16}$ By this method was determined the additive genetic variance $\left(\sigma_{\mathrm{A}}^{2}\right)$. The 'Zucchini Tala' hybrid, genetically uniform, interspersed to determine the environmental variance within plots, allowed to estimate the genetic variance within families, which corresponds to $(3 / 4) \sigma_{\mathrm{A}}^{2}+\sigma_{\mathrm{D}}^{2}$. Because of in the hybrid only the total biological yield was registered (the complete plant with its fruits was weighed), it was not possible to determine the dominance variance for all the characters evaluated in the families. The additive variance was estimated based on the relationship of $\sigma_{\mathrm{A}}^{2}$ with the variance between families $\left(\sigma_{\mathrm{F}}^{2}\right)$, which results in the additive variance estimator as $\hat{\sigma}^{2} A=4 \hat{\sigma} F^{2}$.

The estimates were made assuming diploid inheritance, two alleles per locus, linkage equilibrium in the population, and epistasis absence. Based on the information in Tables 1\&2, the estimated genetic parameters were calculated as follows:

a) Additive variance $\sigma_{\mathrm{A}}^{2}=4=4[(\mathrm{M} 1-\mathrm{M} 2) / \mathrm{pr}]$, from modelo 1 . $\sigma_{\text {fam }}^{2}=$ estimated variance between families

Dominance variance
$\hat{\sigma}^{2} D$
model 2 . Additive Genetic Variance Coefficient $C V_{A}=\frac{\sigma_{A}}{\bar{X}}$ model 1, where $\sigma_{\mathrm{A}}$ is the additive standard deviation and ${ }^{-}$is the phenotypic mean of the trait

\section{Phenotypic variance:}

i. Within families $\sigma_{\mathrm{PW}}^{2}=\mathrm{M} 3$ from Model 1

ii. Between families $\sigma_{\mathrm{PB}}^{2}=\mathrm{M} 1 / \mathrm{pr}$ from Model 1

iii. Between individuals $\sigma_{O}^{2}=\sigma_{F}^{2}+\sigma_{P B}^{2}+\sigma_{P W}^{2}+\sigma_{R F}^{2}, \sigma_{R F}^{2}$ from Model 2.

Heritability in narrow sense: It was determined based on the formula proposed by Nyquist, ${ }^{17}$ which indicates that it is the quotient of the variance of families and the phenotypic variance between families, and is represented as follows $h^{2}=\sigma_{\mathrm{A} /}^{2} \sigma_{\mathrm{P},}^{2}$ where $\sigma_{\mathrm{P}=}^{2}$ phenotypic variance,

$$
\widehat{h}^{2}=\frac{\hat{\sigma}^{2} f}{\hat{\sigma}^{2} P B}=\left[\frac{\left(M_{1}-M_{2}\right)}{p r}\right] /\left[\frac{M_{1}}{p r}\right]
$$

\section{Results and discussion}

The results of the analysis of variance in the experiments 2000 and 2001 of evaluation of half-sib families showed significant differences $(\alpha=0.01)$ between families for the nine fruit and seed evaluated traits (not shown data). All the mean values in the evaluated traits of the Mexican local squash population increased when the population 
passed from four to five combined selection cycle, due to the positive effect of selection. Among them, the weight of fruit and dry weight of seed that they passed from 1.8 to $2.2 \mathrm{~kg}$ and from 58 to $73 \mathrm{~g}$ per fruit (Table 3).

In the evaluation of 'Tala' hybrid interspersed in one row every six families in 2001 (in 2000 has not good quality data because of hail damage), significant statistical differences $(\alpha=0.01)$ were found among rows (or areas) for fruit weight, fruit height, fruit width, pulp thickness, seed length and dry seed weight; and for seed width $(\alpha$ $=0.05$; not shown data), indicating that it was efficient to measure the environmental variation, in accordance with ${ }^{14}$ who proposed to sow experimental plots with genetically homogenous plants to estimate only the intraplot environmental variance type. In that respect, Sahagún ${ }^{18}$ mentions that the estimation of the intraparcel environmental variation provides to the breeders an useful element for estimating the heritability of a trait, when the basic unit of study is the plant.

\section{Genetic variance}

The dominance variance was only measured in second evaluation (2001), since in the first (2000) the Tala hybrid sown to determine the environmental variation was damaged by falling hail and had not satisfactory recovery. Genetic variance was fully determined by additive effects of the genes $\left(\sigma^{2}\right)$, because of estimated dominance variance $\left(\sigma_{\mathrm{D}}^{2}\right)$ (Table 3 ) was low and negative (interpreted as zero) in all the evaluated characters, except for dry weight of seed (DWS) character where it was positive, according with concepts of Hallauer, ${ }^{10}$ Falconer, ${ }^{14}$ Márquez and Sahagún, ${ }^{16}$ Sahagún, ${ }^{18}$ Bernardo, ${ }^{8}$ and
Hallauer ${ }^{10}$ and with results of Rovaris et al., ${ }^{11}$ Rebolloza-Hernández et al., ${ }^{12}$ and Silva-Díaz et al., ${ }^{9}$ in maize, Abbott $\mathrm{L}^{7}$ in creole cebadilla, Peña-Lomelí ${ }^{19}$ in Mexican husk tomato,d Sánchez-Hernández et al (2000) and Sánchez-Hernández (2006) in squash (C. argyrosperma). The additive variance was the alone existing component in all the characters, except in dry weight of seed where $80.7 \%$ of the genetic variance was additive $\left(\sigma_{\mathrm{A}}^{2}\right)$ and $19.7 \%$ of dominance $\left(\sigma_{\mathrm{D}}^{2}\right)$ (Table 3 ). The additive variance was predominant and unique in eight of nine characters studied (negative values of variance of dominance $\sigma_{\mathrm{D}}^{2}$ ). Only the dry weight of seed registered a $\sigma^{2}$ fraction, but very low with respect to the $\sigma_{\mathrm{A}}^{2}$ magnitude (Table 3).

\section{Effect of selection on genetic variance}

The genetic additive variance, was visibly reduced from 2000 to 2001 by effect one cycle of combine selection of half sib families. Reductions varied from $16.6 \%$ in pulp flavor (PF) to $65.7 \%$ and $79.9 \%$ in fruit weight and length of fruit (LF), respectively; whereas the additive genetic coefficient of variance $\left(\mathrm{CV}_{\mathrm{A}}\right)$, diminished from $0.9 \%$ in pulp flavour (PF) to $51.1 \%$ and $52.0 \%$ in length of fruit (LF) and fruit weight (FW), respectively (Table 3 ). The traits with greatest reduction in additive variance due to selection were: fruit length (LF, 79.9.7\%), fruit weight (WF, 65.7\%), fruit width (60.9\%), pulp thickness (PT, 57.6\%) and pulp color (PC, 43.7\%). In pulp flavor the reduction was much lower ( $\mathrm{PF}, 16.6 \%)$. Contrary to expectations, in length of seed (the reduction was almost null $(0.8 \%)$, but in width of seed (WS) was a spectacular increase of $173 \%$ in additive genetic variation (Table 3), probably due to the continuous gene flow from landraces of neighboring farmers.

Table 3 Genetic parameters in two composites of combined selection of half sib families of a Mexican local squash variety 'Round Zucchini' type

\begin{tabular}{|c|c|c|c|c|c|c|c|}
\hline \multirow[b]{2}{*}{ Characterb } & \multicolumn{7}{|c|}{ Estimated Genetic Parametersa } \\
\hline & Year & Mean & $\mathrm{CV}$ & $\sigma_{A}^{2}$ & $\sigma_{D}^{2}$ & CVA & h2 \\
\hline \multirow[t]{2}{*}{$\mathrm{FW}(\mathrm{kg})$} & 2000 & 1.81 & 36.96 & 0.9013 & nd & 52.45 & 75.23 \\
\hline & 2001 & 2.21 & 27.57 & 0.309 & -0.028 & 25.16 & 55.54 \\
\hline \multirow[t]{2}{*}{$\operatorname{LF}(\mathrm{cm})$} & 2000 & 12.5 & 19.32 & 7.4484 & nd & 21.83 & 65.7 \\
\hline & 2001 & 11.6 & 11.39 & 1.4946 & -15.162 & 10.54 & 56.22 \\
\hline \multirow[t]{2}{*}{ WF $(\mathrm{cm})$} & 2000 & 17.41 & 14.06 & 11.9988 & nd & 19.9 & 75.04 \\
\hline & 2001 & 19.66 & 8.95 & 4.6909 & -2.6105 & 11.02 & 69.42 \\
\hline \multirow[t]{2}{*}{ PT $(\mathrm{cm})$} & 2000 & 2.26 & 21.93 & 0.4079 & nd & 28.26 & 71.28 \\
\hline & 2001 & 2.43 & 17.84 & 0.1727 & -0.0821 & 17.13 & 58.04 \\
\hline \multirow[t]{2}{*}{ PC } & 2000 & 1.99 & 46.57 & 1.5087 & nd & 61.72 & 72.39 \\
\hline & 2001 & 1.78 & 53.63 & 0.8494 & nd & 51.81 & 58.34 \\
\hline \multirow[t]{2}{*}{ PF } & 2000 & 1.74 & 29.88 & $0.236 I$ & nd & 27.93 & 56.81 \\
\hline & 2001 & 1.4 & 34.67 & 0.1969 & nd & 31.59 & 55.45 \\
\hline \multirow[t]{2}{*}{ LS (cm) } & 2000 & 10.23 & 8.01 & $0.957 \mid$ & nd & 9.56 & 68.11 \\
\hline & 2001 & 10.37 & 7.6 & 0.9649 & -0.3225 & 9.47 & 69.95 \\
\hline \multirow[t]{2}{*}{ WS (cm) } & 2000 & 4.59 & 9.67 & 0.1889 & nd & 9.47 & 58.91 \\
\hline & 2001 & 4.5 & 10.37 & 0.5161 & -0.236 & 15.96 & 78.03 \\
\hline \multirow[t]{2}{*}{ DWS (g) } & 2000 & 58.78 & 34.39 & 685.352 & nd & 44.54 & 71.56 \\
\hline & 2001 & 73.2 & 29.04 & $4 \mid 4.3896$ & 99.406 & 27.81 & 57.91 \\
\hline
\end{tabular}

(a) $\mathrm{CV}$, variation coefficient (\%); $\sigma_{\mathrm{A}}^{2}$ additive variance estimator; $\mathrm{CV}_{\mathrm{A}}$, additive genetic coefficient of variance $(\%) ; \mathrm{h}^{2}$, heritability (\%); nd: not determined.

(b) FW, fruit weight; LF, length of fruit;WF, width of fruit; PT, pulp thickness; PC, pulp color (scale, I: strong orange; 2: orange; 3 strong yellow; 4: yellow; 5 : light yellow and 6: white); PF, Pulp flavor (scale, I: very sweet; 2: sweet and 3: insipid); LS, length of seed;WS, width of seed; DWS, dry weight of seed.

(c) Dominance variance was not calculated in year 2000 because data were not obtained from Tala homogeneous hybrid in the field. 
By definition, when additive variance is represented as a $\left(\mathrm{CV}_{\mathrm{A}}\right)$ percentage of the mean, $C V_{A}=\frac{\sigma_{A}}{\bar{X}}$, it is a more comparable measurement of additive genetic variance. Based on the $\mathrm{CV}_{\mathrm{A}}$, the reduction of the additive variance from highest to lowest in the studied traits was: $52.0 \%$ in fruit weight $(\mathrm{FW}), 51.1 \%$ in fruit lengthth $(\mathrm{LF})$, $44.6 \%$ in fruit width (WF), $39.3 \%$ by pulp thickness (PT), 37.5\% by dry weight of seed (DWS), $16.0 \%$ by pulp color (PC) and $0.9 \%$ by seed lengthth (LS); whereas that, the increases occurred were: $5.9 \%$ in pulp flavor (PF) and 68.5\% in seed width (WS) (Table 3). These results suggest that, when farmers or breeders combine in situ conservation of important local populations with participatory selection, the genetic additive variance of populations is reduced by effect of the selection process. The magnitude of reduction could be given by the used method of selection and the selection pressure applied.

\section{Heritability $\left(h^{2}\right)$}

The estimated heritability in narrow sense $\left(\mathrm{h}^{2}\right)$ can be considered high the nine evaluated characters, because it varied between $56.81 \%$ and $75.23 \%$ for year 2000 evaluation, and among $55.45 \%$ to $78.03 \%$ for 2001 year. The smaller values of heritability in year 2000 corresponded to flesh flavor and width of seed traits; and the greater corresponded to length and width of fruit (Table 4); whereas in composite of year 2001 also the character flesh flavor presented the lowest value, and the highest values were for width and length of seed. It must be considered that estimated heritabilities correspond to the families, so its predictive sense only can be used properly for half sib family selection case. In addition, it is probable that in this study the $\mathrm{h}^{2}$ could be a little bit overestimated, since the half sib evaluated families were obtained from a open pollinated population, which overestimates the $\left({ }_{\mathrm{F}}^{2}\right)$, because it contain some portion of full sib. ${ }^{17}$

Table 4 Percentage change (-: reduction, +: increase) in additive variance and heritability by effect of a cycle of combined selection

\section{Estimated Genetic Parametersa}

\begin{tabular}{lccc} 
Character & $\sigma_{A}^{2}(\%)$ & CVA & h2 \\
& & & \\
\hline FW (kg) & -65.7 & -52 & -37.5 \\
LF (cm) & -79.9 & -51.1 & -14.4 \\
WF (cm) & -60.9 & -44.6 & -7.5 \\
PT (cm) & -57.6 & -39.3 & -18.1 \\
PC & -43.7 & -16 & -14.1 \\
PF & & & \\
LS (cm) & -16.6 & -5.9 & -2.3 \\
WS (cm) & 0.8 & -0.9 & 2.7 \\
DWS (g) & 173 & 68.5 & 32.4 \\
& -39.5 & -37.5 & -19
\end{tabular}

$\sigma^{2}$ additive variance estimator; $\mathrm{CV}_{\mathrm{A}}$, additive genetic coefficient of variance (\%); $h^{2}$, heritability (\%).

(b) FW, fruit weight; LF, length of fruit;WF, width of fruit; PT, pulp thickness; PC, pulp color (scale, I: strong orange; 2: orange; 3 strong yellow; 4: yellow; 5: light yellow and 6: white); PF, Pulp flavor (scale, I: very sweet; 2: sweet and 3: insipid); LS, length of seed;WS, width of seed; DWS, dry weight of seed
Certain inconsistency observed among the values of $\mathrm{CV}_{\mathrm{A}}$ and those of $\mathrm{h}^{2}$, because some characters shown similar heritability values but they have very different values of $\mathrm{CV}_{\mathrm{A}}$ and viceversa in both evaluations. Peña ${ }^{19}$ indicates that the inconsistency among $\mathrm{CV}_{\mathrm{A}}$ and $h^{2}$ is a consequence of the parameters estimation form, because whereas the $\mathrm{CV}_{\mathrm{A}}$ contains solely $\left(\sigma_{\mathrm{A}}^{2}\right)$, the $\mathrm{h}^{2}$ involves $\left(\sigma_{\mathrm{A}}^{2}\right)$ and the complement of the $\left(\sigma^{2}{ }_{\mathrm{p}}\right)$, reason why not always is to be expected a perfect correlation among $\mathrm{CV}_{\mathrm{A}}$ and heritability (Table 3 ).

\section{Effect of selection on heritability}

The found heritability values could be considered high, still after that the population has accumulated four cycles of mass selection and one cycle of combined selection. In spite of high heritability magnitudes were very similar in both cycles $(2000,2001)$, which oscillated between 55 to $78 \%$, the cycle of combined selection applied reduced the heritability in six and increased it in two of the nine studied traits. The reduction in heritability as a result of the selection, varied from $2.7 \%$ in pulp flavor (PF) to $37.5 \%$ in fruit weight $(\mathrm{FW})$; while the increases were in seed characters $(2.7 \%$ for length of seed and $32.4 \%$ for width of seed). The increase in heritability in length and width of seed could be attributed to the gene flow, made by bees, from squash landraces of neighboring farmers to the selected variety. Local squash varieties of $C$. pepo have seed much bigger than zucchini type. It must be remembered that the seed yield is emphasized in the selection criterion applied, because the seed is the most economically valuable product of the pumpkin crop in Mexico. In general, the magnitude of additive genetic variance and heritability mainly diminish, but in some traits they increase a consequence of the linkage disequilibrium by the application of selection, the gene flow and recombination by open pollination (bee work) in the variety. ${ }^{20-23}$

\section{Conclusion}

All the evaluated traits (ripe fruit yield and quality, and seed yield) in a Mexican local squash variety were higher after the application of a cycle of combined selection of half sib families.

The mayor genetic variance of yield and quality of ripe fruit and seed yield in the selected variety, and their high heritability, indicate that the additive effects of the genes, were more important than those of dominance, in the phenotypic expression of the traits. The magnitude of additive genetic variance and heritability mainly diminish, but in some traits they increase as a consequence of the linkage disequilibrium by the application of selection, the gene flow and recombination by open pollination in the variety.

\section{Acknowledgments}

Agradecimiento a Mc Knight Foundation por el financiamiento del "Milpa Project".

\section{Conflicts of interest}

The authors declare that there was no conflict of interest.

\section{Funding}

None.

\section{References}

1. Basurto-Peña F, Castro-Lara D, Mera-Ovando LM, et al. Ethnobotany of WS Cultivated Pumpkins (Cucurbita spp.) In Central Valleys of Oaxaca, Mexico. Agro Productivity. 2020;13(6):47-53. 
2. Sánchez-Hernández MA, Mejía-Contreras JA, Villanueva-Verduzco C, et al. Genetic Resources in the "Calabaza Pipiana" Squash (Cucurbita argyrosperma) in Mexico: Genetic Diversity., Genetic Differentiation and Distribution Models. FPS. 2018.

3. Montes HS. Calabazas (Cucurbita spp.), In: Avances en el Estudio de los Recursos Fitogenéticos de México. 1991. p. 239-50.

4. Ed Ortega P, Palomino H, R Castillo G, et al. Sociedad Mexicana de Fitogenética. Universidad Autónoma Chapingo. Chapingo, México. 2020. 347 p.

5. Cerón-González L, Legaria-Solano JP, Villanueva-Verduzco C, et al. Genetic diversity in four species of Mexican squash (Cucurbita spp.) Rev Fitotec Mex. 2010;33(3):189-196.

6. Méndez-López A, Villanueva-Verduzco C, Rojas-Martínez RI, et al. Genetic diversity of squash shrubby parthenocarpic genotypes using molecular genetic markers. Revista Mexicana de Ciencias AgrícoWS. 2019;10(1):1-9

7. Abbott L, Pistorale S. Determination of components of variance and heritability in Creole barley (Bromus catharticus Vahl.). Agriscientia. 2010;27(2):115-123.

8. Bernardo R. Breeding for Quantitative Traits in Plants. Stemma Press. Woodbury, MN, USA; 2002. 369 p.

9. Silva-Díaz R, García-Mendoza P, Faleiro-Silva D, et al. Estimation of variance components and genetics parameters in a segregating population of tropical maize. Bioagro. 2018;30(1):67-77.

10. Hallauer A, Carena M, Miranda-Filho J, et al. Quantitative Genetics in Maize Breeding. Third edition. Iowa State University Press. Ames, Iowa; 2010. 243 p.

11. Rovaris SRS, Araújo PM, Garbuglio DD, et al. Estimates of genetic parameter in maize commercial variety IPR 114 at Paraná State, Brazil. Acta Scientiarun Agron Maringá. 2011, 33(4):621-625.

12. Rebolloza-Hernández H, Castillo-Gutiérrez A, Carapia-Ruíz VE, et al. Estimation of genetic parameters and selection of S1 lines in a segregating population of tropical maize. Revista Mexicana de Ciencias Agrícolas. 2016;7(8):8:1893-1904.
13. Sánchez HMA, Villanueva V C, Sahagún C J, et al. Genetic variation and response to combined selection in a creole variety of pipiana squash (Cucurbita argyrosperma Huber var. Stenosperma). Rev Chapingo $S$ Hort. 2000;6(2):221-240.

14. Falconer DS. Introducción a la Genética Cuantitativa. Ed CECSA. México DF. 1989. 383 p.

15. Molina G, Jose D. Introduction to Population and Quantitative Genetics (Some Implications in Genotechnics). In: AGT, editor. México; 1992. $349 \mathrm{p}$.

16. Márquez SF, Sahagún C. Estimation of genetic variances with maternal half sib families. Maydica. 1994;39:197-201.

17. Nyquist WE. Estimation of heredability and prediction of selection response in plant populations. Critical Reviews in Plant Science. 1991;10(3):235-322.

18. Sahagún CJ. Estimation of the intra-parcel environmental variance in North Carolina Design III. Revista Fitotecnia Mexicana. 1996;19:1-8.

19. Peña-Lomelí A, Molina-Galán JD, Sahagún-Castellanos J, et al. Genetic parameters in the CHF1 Chapingo variety of husk tomato (Physalis ixocarpa Brot.), Rev Fitotec Mex. 2004;27(1):1-7.

20. Márquez SF, AR Hallauer. Influence of sample size on the estimation of genetic variances in a synthetic variety of maize. I: grain yield. Crop Sci. 1970;10:357-361.

21. Robinson HF, CC Cockerham. Estimation and meaning of genetic parameters. Latin American plant breeding. 1965;2(1\&2):23-38.

22. Sánchez de la Vega G. From the cave to the table, and now to the genomic laboratory: the diversity of pumpkins in Mexico. Oikos. 2017;17:11-17.

23. Estimation of Genetic Parameters in Pipiana Squash (Cucurbita argyrosperma Huber). Rev Fitotec Mex. 2006;29(2):127-136. 